\title{
Reputations and national identity, or, what do our heroes say about us?
}

James J. Smyth and Michael A. Penman

\section{(2) OpenEdition \\ 1 Journals}

\section{Electronic version}

URL: http://journals.openedition.org/etudesecossaises/143

DOI: 10.4000/etudesecossaises. 143

ISSN: 1969-6337

\section{Publisher}

UGA Éditions/Université Grenoble Alpes

\section{Printed version}

Date of publication: 31 March 2005

Number of pages: 11-23

ISBN: 2-84310-061-5

ISSN: 1240-1439

\section{Electronic reference}

James J. Smyth and Michael A. Penman, « Reputations and national identity, or, what do our heroes say about us? ", Études écossaises [Online], 10 | 2005, Online since 31 March 2005, connection on 07 September 2020. URL : http://journals.openedition.org/etudesecossaises/143 ; DOI : https://doi.org/ 10.4000/etudesecossaises.143 
James J. Smyth \& Michael A. Penman

\section{Reputations and national identity, or, what do our heroes say about us?}

JAMES J. SMYTH ET AL. University of Stirling.
It seems appropriate to be writing this introduction in the same week as the new Dictionary of National Biography (ODNB) is launched and the Biographical Dictionary of Scottish Women celebrates the completion of the commissioning of its entries. Whatever scruples some historians may have over the worth or relevance of biography, there is no doubting its popularity; the tables and shelves of every bookshop groans under the weight of biographies and ghosted autobiographies of past and present football legends and current pop stars. Much of this output represents either an exercise in marketing or cashing in on transient fame, but, as the two volumes mentioned above illustrate, academia has retained, or rediscovered, its own fascination with biography.

The motivation behind biographical dictionaries is to assemble a record of a particular grouping or entity, most notably on a national basis. While they have a collective ambition - the national dictionary, women in Scotland - they remain necessarily selective; no matter how wide ranging the editors may seek to be, they simply cannot include everyone. What wider purpose they serve, in terms of what insights they offer into a nation's history or psyche, is not clear. As contributors to both of these dictionaries, we are aware that they are collections of entries by individual scholars, rather than singleauthored entities. Even in the case of the dictionary of Scottish women, with its twin aims of not simply recording, but also reexamining and re-assessing the historical account through the prism of gender, it seems to us that the former purpose must predominate. As Sue Innes has written, «We face the basic task of finding historical women...» (Innes, 2003, p. 14). The DNDB has a less complicated agenda. Its web-site explains that the dictionary's 50,000 entries contain the «biographies of the men and women who shaped all aspects of Britain's past» (www.oxforddnb.com/ oxforddnb/info/). If one removed 
the words « all aspects of », this would read much like the Victorian model of national biography. J.R. Findlay, the private donor whose money established the Scottish National Portrait Gallery in the late nineteenth century, explained the purpose of the gallery as, «the illustration of Scottish History and the men who made that history». (J.R. Findlay to Secretary of the Board of Trustees, 3 Dec. 1895, NAS NG 7/6/1/14). And it is exactly this taint of Victoriana - great men, or great figures determining events and shaping history - that has led some historians to dismiss biography altogether (Pimlott, 2004).

Our purpose here is not to attempt any sort of complete account of famous Scots, nor is it to rediscover forgotten, though undoubtedly worthy individuals, or to correct any existing biases in the historical account. Our concern lies, at least initially, with the existing canon, that is with those figures whom historians would recognise as among the most significant in Scotland's history. Our focus lies on the famous and on the reasons why their fame has been sustained or declined over time.

Our approach has emerged out of an undergraduate course which we devised on famous characters in Scottish history. The object of the course has been not just to provide a series of biographies but to look at the processes by which certain individuals have become famous or significant within the history of Scotland. Our aim is to challenge students to look beyond the popular view or perception of famous historical figures, and to examine how reputations could be made and lost, interpreted and reinterpreted over time. Essentially we are giving our students a course in sources and methods (though without telling them), and, along the way saying something about Scotland and Scottish identity.

However, the academic structure of an undergraduate course is something of a limitation or obstacle to our own wider ambitions. Our choice of figures has been constrained by the need to select individuals on whom there already exists an accessible academic literature. But, it is our belief that in creating and sustaining a reputation the work of academics is not of particular significance. In challenging the popular view of a figure, we have become increasingly aware of how difficult it is to make much if any impact upon that perception beyond the lecture theatre or seminar room. In the face of an icon like Wallace - and the power with which the legend can be 
represented in a medium like film - then academic criticism of «Braveheart» can be so much pissing in the wind.

This is not to denigrate either the «academic» or the «popular » view, nor does it necessarily mean that the popular and the academic need be strictly opposed to one another, or hermetically sealed off from each other. It seems clear that the popular image of famous figures, as revealed in chap books, short pamphlets, even spoken stories, relied partly on some awareness of the recognised authorities on the lives of the individuals concerned. What we are suggesting is that once an image has become established it is remarkably immune to academic criticism and revision.

\section{Key Questions}

While it is our duty as historians to challenge the preconceptions that exist about famous figures, to question their reputations, we do not think that we should leave it at that. In fact, we want to go backwards in a sense, and examine where these preconceptions come from. What are the factors or ingredients that go together to cement a reputation? Is there a folk tradition, and if so, how is it expressed? Are literature and other forms of artistic representation critical in making a popular reputation? Are visual images particularly important, given that they can sum up a life in a short series of vignettes that are easy to remember? Does the professional heritage industry have an important role to play?

It seems to us that there are three questions to be confronted:

1. The popular image - what makes it? The popular image need not be a singular view, but what goes into the recipe which creates a genuinely popular image? By this we mean, a figure who is instantly recognisable among the mass of the population, not just among academics or enthusiasts.

2. How do we research a popular image? What stress or explanatory power should we give to various elements? Could we quantify the process by which a reputation is made? For instance, the number of statues commemorating a specific figure, the number of streets named after a figure?

3. Is there a national model of the popular historical figure? 
Or, put another way, do these figures and their enduring popularity say anything about national histories and identities?

\section{Biography or Reputation}

There have been recent, and current, explorations of reputations, with at least three publishers' series using the same title we are aware of. In the late 1980s Batsford, and in 1998 Longman brought out series aimed at young readers. The intent clearly being the admirable one of introducing young readers to historical debate and interpretation.

More significant is the Arnold series of academic biographies, currently numbering ten but with more in the pipeline. Published works so far are: Thomas More, Thomas Becket, Disraeli, Louis XVI, Napoleon, Nixon, Neville Chamberlain, Cromwell, Gorbachev and Thatcher. The general editorial preface asserts that:

There is more to the series than illumination of ways in which recent discoveries or trends have refashioned identities or given actions new meanings... The corresponding aim is to provide readers with a strong sense of the channels and course of debate from the outset: not a Cook's Tour of the historiography, but identification of the key interpretative issues and guidance as to how commentators of different eras and persuasions have tackled them.

We can all agree with the merit behind this approach. It echoes the thinking behind our own taught course. It seems to us that this is the direction biography ought to take if it is to make a serious contribution to historiography. It is similar to the argument of Richard Holmes in his call for «virtually a new discipline, which might be called comparative biography» (Holmes, 2002, p. 15-16). Unfortunately, not everyone agrees. A recent review of a biography of Isaac Newton complains that, "Everyone's writing about reputations rather than people nowadays", and called for more of the story of Newton's life rather than "pontifications on... cultural significance ». (The Independent on Sunday, 25 May 2003). And just when we thought we were doing something new and interesting, we discover we are in the middle of a backlash. That said, biographical studies ignore the personal life of their subject at their peril. The human aspects of «a life», the narrative of an individual life 
history can help to humanise history. Our own course insists that students appreciate the «life and times» of the selected figures, as well as their subsequent reputations.

The selection of subject matter in all three series appears to be eclectic in approach, essentially any and all famous figures in history. Holmes's «comparative biography», for all its emphasis on literary figures, does not offer a model beyond the practice of biography itself. What is distinctive about our approach is that firstly we are operating on a national basis (and would welcome parallel national studies). Secondly, that our concern is with the popular perception more than the academic analysis. To paraphrase Richard Finlay, « we do not wish to destroy the myth, but to understand it» (Finlay, 1997, p. 123).

\section{Public Memorials or Urban Wallpaper: Chalmers, Livingstone, Dewar}

Are there characters whose life and work is so important that they cannot be ignored by succeeding generations? Or, has a popular reputation nothing to do with significance, but more with a dramatic or romantic life story that simply captures the imagination in the way that a fictional character might?

In the centre of Edinburgh, separated by no more than half a mile, there are statues honouring two giants of nineteenth century Scotland. The first is Thomas Chalmers, situated on George Street at the junction of Castle Street and North Castle Street. Thousands of people must walk past that statue every day but how many even bother to look at it? That lack of interest may be because such public structures, over time, simply fade into the background, becoming part of the urban wallpaper. We no longer look at them because we are so familiar with them. It is the tourist who stops to look and admire, not the local inhabitant.

However, Chalmers has been forgotten. Not among academics. Historically and intellectually there has been considerable interest in Chalmers through attention given to the Disruption and to reform of the poor law. A lot of this interest had been to debunk his reputation, but at least he has not been ignored by historians; a quick check list of publications would indicate that. There can be no doubt that Chalmers was a giant 
of nineteenth century Scotland, a man whose life and memory was revered by many.

And, in the early twentieth century even Protestant social reformers who disagreed with Chalmers' belief in unfettered political economy, still included him as one of the paragons of Scottish history alongside Wallace and Knox (Stewart, 2001, p. 21). Moreover, it does not seem beyond the bounds of probability to imagine that with the rise of the New Right in the 1970s and 1980s, and even with New Labour in the 1990s, Chalmers may have been rediscovered as having a contemporary relevance to the issues of welfare and community. However, our view is that any vox pop that asked about Chalmers would get an almost unanimous «don't know» in response.

Chalmers' fall from popular grace seems to have occurred quite early in the twentieth century, and to have taken place very quickly. Judging by entries in the annual index to the Glasgow Herald (1906-1984), Chalmers was referred to quite often in the pre-1914 years and during the First World War itself. After 1920, however, he is mentioned only fleetingly if at all. Perhaps the reality of mass, long-term structural unemployment alongside working class animosity to the means test explains the lack of references to Chalmers. Yet, Protestant Scotland in the interwar years, was searching for the « godly commonweal» that had so exercised the «reverend professor ».

In sharp contrast is the reputation of the subject of our second statue. Located at the far east end of Princes Street Gardens is a sculpture of David Livingstone. Two items of interest are immediately apparent about this structure. One is that it is literally in the shadow of the Scott Monument. The second is that there is no detail other than a single word, «Livingstone ». David Livingstone has been the subject of a series of recent biographies but then so has Chalmers, if not to quite the same extent. Why is it Livingstone who remains immediately identifiable today?

Was Livingstone's enduring popularity secured by the meeting with Stanley, and that almost unbelievably understated introduction? What Michael Fry has described as « the most famous conversation of the century... so stilted as to have soon turned into an overworked gag in the music-halls » (Fry, 2001, p. 148). The joke has certainly outlived the variety theatres, and has become almost an item of everyday speech. Is there anyone reading this who has not either heard, or themselves 
said, the punch-line «I presume »? Perhaps in Livingstone's life this was the «structural moment» which literary commentators see as so important in establishing a reputation (we owe this point to Rory Watson of Stirling University).

As we all know, there is a great deal to Livingstone, and a great deal about his life which remains relevant to us today. Ruaridh Nicoll, a columnist in The Observer last year, wrote that as a missionary and an explorer Livingstone was no great shakes, but that, nonetheless, "he is one of Britain's greatest » (The Observer, 15 June 2003). Niall Ferguson made more or less the same point when he admitted that his expected debunking of Livingstone had turned into hero-worship («My Hero », $B B C$ History, March 2003).

The causes of mission and empire - with which Livingstone's early reputation was inextricably linked - have faded and today have little support or appeal within Scotland. But, Livingstone's attack on slavery, his anti-racism and belief in a common humanity, represent a cause with which many people today do feel a commitment to. In short, he remains relevant and sympathetic.

And yet, at the same time, Livingstone's reputation can be seen as being «manufactured». In sharp contrast to the eclipse of Chalmers, the 1920s witnessed the cementing of Livingstone as a Scottish national icon. In one of the earliest examples of the «Heritage industry», or «history as themepark», the " David Livingstone National Memorial » was established in the tenement block in Blantyre where the great explorer was born and grew up. The Centre opened its doors in 1929 and by 1946 it had hosted one million visitors (Glasgow Herald, 13 August, 1946).

Both Chalmers and Livingstone are represented by statues in the centre of Edinburgh, but the fate of neither reputation has been determined by those statues. Just as no-one is aware of Chalmers on his plinth in George Street, few know that Livingstone is located in Princes Street gardens. This neglect begs the question how would we commemorate a famous figure today? Well, in the case of Donald Dewar, Scotland's first First Minister, it has been by constructing a statue, a piece of public art the Victorians would have recognised, though possibly not fully appreciated.

It is not exactly clear why that decision was made, but it does seem, at least initially, somewhat old-fashioned. This response may be unfair and miss the point, since we are informed that 
the work is «the most important recent example of figurative memorial sculpture». (Herald, 8 May 2002). But, at nine feet tall, on a plinth of only one metre, the bronze figure is hardly monumental in the Victorian style. Dewar is dressed not in a roman toga but in his usual work-day clothes. The effort seems to have been to capture the essence of the man which includes a lack of pretension and genuine modesty. The statue which, we predict, will gradually fade into the background, has been kept in the news by the repeated vandalism of it. Apart from the usual traffic cone, there has been actual damage to Dewar's spectacles. But, and this seems to us a very human touch, friends of the First Minister have suggested that this only serves to make the statue more life-like, since Donald Dewar's glasses were usually held together by sellotape or string.

As one of the architects of devolution and Scotland's effective prime minister, it was clearly felt that Dewar's passing had to be marked in a public and symbolic way; hence the statue. On the plinth are Dewar's own words, «There Shall be a Scottish Parliament.» Of course Dewar's legacy was contested both when he was alive and at his death. In the 1980s, labouring under the frustration of the apparent permanent Tory majority in England, one pro-devolution journal depicted Dewar as Burn's «timrous beastie» (Radical Scotland, no. 9, June/July 1984). Amid all the plaudits to Dewar's career and personality, the correspondence page of the Herald contained at least one letter pointing out (critically) that Dewar had died a millionaire.

Nonetheless, Dewar's reputation was at a high point at the moment of his death. Whether it can survive the never-ending scandal that is the new Parliament building remains to be seen. The early sessions of the Fraser Inquiry into the escalating costs of Holyrood seemed to threaten to permanently demolish Dewar's memory. The final published Report lays most of the blame on the senior civil servants while stating that there was «no single villain of the piece» (The Herald, 16 September 2004). Whether this will be enough to exonerate Dewar in the public eye remains to be seen. It may well be that Dewar's reputation is inextricably bound up with that of the building he was so determined to see constructed.

It would be a mistake, however, to dismiss this as simply a local matter of corruption or incompetence. Throughout Europe current and recent political leaders are facing, or are threatened with, similar scrutiny: Chirac, Kohl, Berlusconi, 
even Tony Blair. And, beyond these immediate scandals, we are forced to ask the question, is it possible to have heroes today?

In the age of the mass media the constant intrusion of that media make it impossible for any character to remain unblemished. If, as Jayne Lewis (in this collection) says about Mary Queen of Scots, that everyone knows who she was only because no-one knows who - or what - she was, how do we deal with individuals about whom we appear to know more or less everything? Could John F. Kennedy have achieved his almost mythic status in modern American history, if his womanising had been subject to the same forensic scrutiny as Bill Clinton's? Closer to home, could Keir Hardie's reputation as something of a secular saint have survived tabloid investigation into the «true» nature of his relationships with the Pankhursts? What has Edwina Currie done for John Major's «reputation »? Are people right to be cynical about leaders, or does the constant and prurient examinations of public lives mean that there cannot be any more heroes?

\section{Heroes and National Identity}

Heroes are, for the most part, national. It is true that certain individuals can claim genuine international or world recognition and respect, even in their own lifetime; Nelson Mandela springs to mind. But most heroes, or even just famous figures, are located in a particular country or nation. Winston Churchill was recently voted the most famous Briton in a television poll, but Churchill, for all his international significance in resisting Hitler, remains essentially a local hero. Indeed, it is a moot point if he would have received a similar accolade in a poll only of Scottish or Welsh viewers asked to nominate a «British » figure. More than this we know that one nation's hero can be another (and usually neighbouring) country's villain. Wallace may be Scotland's Braveheart, but he does not get that accolade south of the Tweed. Henry V, as immortalised by Shakespeare, is one of England's great heroes, but, if there were historical courts of law, the French could prosecute him as a war criminal.

This is not to say that national figures do not have a resonance beyond their national borders. After all Wallace has that, 
and in spades because of that film. But most, if not all, figures perform - at least initially - on a national stage. And they contribute - again at least initially - to a national history and a sense of national identity.

Would parallel studies of famous figures say anything significant about differing national histories and cultures? If Scotland had remained independent would her list of heroes be different? Would Bruce dominate over Wallace? As a stateless nation we Scots do not have « official » heroes, we do not have a Pantheon or the pantheonisation of the French. But, does that make the popularity of Scottish heroes more genuine? More truly popular than populist?

We would suggest that there are effectively two rival ways, or narratives, of identifying and explaining Scotland's heroes, and these can be related, roughly, to rival political perspectives. One is a left wing/nationalist viewpoint which emerges out of and echoes the earlier mythology of the «lad o'pairts ». In the nineteenth century, the image of the upwardly mobile young man reinforced the middle classes'belief in laissez faire and meritocracy against the inherited and unfair advantages of the aristocracy. By the late twentieth century, however, the «lad o'pairts» had become more identified with the working class, and especially the fast-disappearing skilled manual workforce of industrial Scotland. Indeed, a common remark, and very often expressed as a complaint, is that in Scotland, contemporary figures need to be working class before they can be recognised. Both periods have projected their values backwards, and so Wallace (representative of the people and naturally noble) has remained the greater hero, with Bruce (an ambitious and ambiguous aristocrat) relegated to a follower of Wallace's dream of an independent nation. Whether we are democratic enough to include women in our pantheon of heroes remains to be seen, though the forthcoming Biographical Dictionary of Scottish Women ought to make some impact.

The second narrative is that of a conservative/elitist perspective which is uncomfortable with the recent past and contemporary direction of Scottish politics and culture. This can be summed up in the perennial complaint that the Scots love failures and, the logical corollary, are suspicious and resentful of success. It is an argument made by the Conservative historian Michael Fry, and was given public expression recently in the responses to a newspaper commissioned opinion 
poll (Scotland on Sunday, 29 December 2002) to find the «Greatest Ever Scot».

The director of the right-wing think tank, the Adam Smith Institute, complained about how the selection revealed Scots as «better disposed to the culture of tartan, sprigs of heather and Scottie dogs than they are to the true great thinkers who helped shape the world». Malcolm Rifkind (ex-Secretary of State for Scotland, and ex-Foreign Secretary) remarked, « in Scotland we concern ourselves more with people who failed than those who succeeded ».

This appears to be such an instinctive response that one wonders whether Pirie or Rifkind actually read the list; where is the concern with failure in choosing a Nobel Prize winner? Out of a choice of twelve figures, Alexander Fleming was voted top. What this knee-jerk reaction reveals is how far out of touch Scottish Conservatives are with modern Scotland. A recent article in the ferociously anti-devolutionist Scotsman, bemoaned the lack of recognition given to Adam Smith in his native land, and, in a nod towards conspiracy theory, suggested that a «subtle left-wing bias against what he is presumed to have stood for» was the explanation for this (Kerevan, 2004). The author, an ex-Trotskyist, managed to write his piece without once referring to how Conservatives and free-marketeers have shamelessly exploited Smith's reputation for years, or considering that the association of Smith with unpopular policies such privatisation of the health service might possibly explain the neglect. Perhaps this right-wing complaint is simply a back-handed compliment to the «independent-minded and egalitarian outlook... [that is] a characteristic part of the Scottish spirit» (Watson, 1984, p. 1). And if the Scots do embrace failure, we can ask why are there no Tory heroes - they have been failing consistently in Scotland for half a century.

Scottish heroes seem to need to be validated by connection with the general population (the people). This is difficult to reconcile with the popularity of Mary Queen of Scots and Bonnie Prince Charlie, two of our more internationally recognisable heroes. The romance of their failures obscures the uncomfortable realities behind their dynastic ambitions; the throne of England. However, as Murray Pittock has argued, the Jacobite cause has become part of the nationalist cause, regarded less as 
a bid for personal power than as emblematic of opposition to a unitary British state (Pittock, 1991).

Of course, struggling, and possibly dying, for a cause is often what makes a life heroic, and our heroes seem to resonate more when they are associated with a cause. This could lead to charges of opportunism as historical figures are simply appropriated to serve current political ends, as in France with the National Font's identification with Joan of Arc. Yet, whatever legitimacy a political party may seek in national heroes, it is not evident that the tactic can be easily translated into votes. There can be little doubt that «Braveheart» had a significant cultural impact within Scotland, but the film's success did not lead to an upsurge in support for the Scottish National Party, even though the SNP sought to identify itself with Wallace. At the same time, however, the continuing popularity of Wallace owes little to direct or immediate political issues. Neither Hollywood nor nineteenth century Liberal Unionism created the Wallace myth, though both have helped it to thrive in new circumstances (Morton, 2001).

Perhaps, a heroic or iconic figure, if their reputation is to be sustained, needs to be flexible, to be open to interpretation and re-interpretation. The less we know of the precise details of the individual life the better. The canvas is never entirely blank, but some empty spaces may be necessary. Yet, surely there is a limit to this process. Figures cannot simply be reinterpreted or reinvented at will. As the fate of Thomas Chalmers indicates, public monuments and academic tomes are not enough to sustain a reputation.

\section{Bibliography}

Brown S.J., Thomas Chalmers and the Godly Commonwealth in Scotland, Oxford, 1982.

Ferguson N., « My Hero », BBC History, March 2003.

Finlay R., "Heroes, Myths and Anniversaries in Modern Scotland», Scottish Affairs, 18, 1997, p. 108-125.

Fry M., The Scottish Empire, East Linton, 2001.

Glasgow Herald.

Glasgow Herald Index.

Holmes R., «The Proper Study?», in P. France \& W. St Clair eds., Mapping Lives: the Uses of Biography, Oxford, 2002, p. 7-18. 
Innes S., «Reputations and Remembering: Work on the first Biographical Dictionary of Scottish Women", Études écossaises, no., 9, 2003.

Kerevan G., «It is time to honour our forgotten son», The Scotsman, 9 August 2004.

Lewis J., Mary Queen of Scots: Romance and Nation, London, 1998.

Morton G., William Wallace: Man and Myth, Stroud, 2001.

National Archives of Scotland (NAS), NG7, « Scottish National Portrait Gallery, 1871-1985 ».

Nicoll R., «Livingstone Lives », The Observer, 15 June 2003.

Pimlott B., «Picture This », The Guardian, 28 August 2004.

Pittock M.G.H., The Invention of Scotland: the Stuart myth and the Scottish Identity, 1838 to the Present, London, 1991.

Radical Scotland.

Ross A., David Livingstone: Mission and Empire, London, 2002.

Scotland on Sunday.

Stewart J., «"Christ's Kingdom in Scotland”: Scottish Presbyterianism, Social Reform, and the Edwardian Crisis », Twentieth Century British History, 12, 1, 2001, p. 1-22.

Watson R., The Literature of Scotland, Basingstoke, 1984. 